\title{
Mating type loci analysis indicates that Villosiclava virens, the casual agent of false smut disease of rice, is a homothallic fungus
}

\author{
Rongtao Fu, Chuanchun Yin, Qiming Deng, Ping Li \& Aiping Zheng \\ Rice Research Institute, Sichuan Agricultural University, 211 Huiming Road, Wenjiang District, Chengdu City, Sichuan \\ Province, China
}

Author for correspondence: Aiping Zheng, e-mail: aipingzh@163.com

\begin{abstract}
Villosiclava virens (anamorph: Ustilaginoidea virens) was isolated from infected rice plants, where it caused false smut. Similar to other ascomycetes, the sexual compatibility of $V$. virens is controlled by the mating type (MAT) locus. In this study, we applied a PCRbased approach to screen mating type genes in the single asexual spore isolate. Our results showed that $V$. virens possesses the two master genes required for mating (MAT1-1-1 and MAT1-2-1), suggesting that this fungus is likely to be homothallic. Mating type primer pairs were developed to genotype the single ascospore isolates from different places in China. These analyses provided further evidence that $V$. virens is a homothallic species and suggest novel genetic mechanisms of sexual reproduction in $V$. virens.
\end{abstract}

Key words: Ustilaginoidea virens, asexual spores, homothallic, MAT, multiplex-PCR.

\section{INTRODUCTION}

Villosiclava virens (Nakata) E. Tanaka \& C. Tanaka is the causative agent of the important false smut of rice (Oryza sativa L.) and maize (Zea mays L.). The anamorphic state of the causal fungus was called Ustilaginoidea virens (Cooke) Takah. (Takahashi, 1896). The teleomorphic state of this fungus is allied with the family Clavicipitaceae and named Claviceps virens M. Sakurai ex Nakata (Sakurai, 1934). However, phylogenetic analyses have demonstrated that Ustilaginoideae species are not allied with the genus Claviceps (White et al., 2000; Bischoff et al., 2004). Therefore, a new genus Villosiclava was proposed and $V$. virens has been used as the name for the rice false smut fungus (Tanaka et al., 2008). The pathogen can infect roots at the young seedling stage and rice coleoptiles and staminal filaments at the earlier bolting stage (Tang et al., 2013). The typical symptom of rice false smut is the formation of greenish spore balls in spikelets, which are covered by an abundance of chlamydospores. The spore balls are initially yellow and turn greenish black with maturity, which is when they contaminate the rice grains. Ustiloxins are an additional concern for humans and livestock (Koiso et al., 1994). Villosiclava virens can form conidia and ascospores (Fu et al., 2012), which are often the source of infection. The sclerotia of $V$. virens, which often form on the surface of mature spore balls, may germinate and produce sexually reproductive stages of the fungus (Singh \& Dubey, 1984). Sexually reproduction results in genetic variation and contributes to evolution.
The sexual cycle of the pathogen plays an important role in disease epidemiology (Hayden et al., 2003). Mating type genes are the master loci that govern sexual reproduction and development in fungi (Metin et al., 2010; Butler, 2010), whereas sexual identity in plants and animals is known to be governed by genes located on the sex chromosomes (Fraser \& Heitman, 2005; Marais \& Galtier, 2003). Fungi can reproduce by selfing or outcrossing. In heterothallic ascomycetes such as Tuber melanosporum Vittad. (Rubini et al., 2011), mating requires a partner of the opposite mating type. In different strains, the genes of opposite mating types are dissimilar sequences: one encodes an alpha-box-domain protein (MAT1-1), and the other encodes a high mobility group (HMG) protein (MAT1-2) (Turgeon $\&$ Yoder, 2000). In contrast to heterothallic species, in most homothallic ascomycetes a single strain contains the genes for both transcription factors, MAT1-1 and MAT1-2. This genetic organization confers self-fertile mating ability (Debuchy \& Turgeon, 2006; Yun et al., 2000). These genes in homothallic fungi are usually linked, but in some case they are not, such as in Aspergillus nidulans (Eidam) G. Winter (Paoletti et al., 2007).

Similar to other ascomycetes, sexual reproduction in $V$. virens is controlled by the Mat loci. In previous studies, Yokoyama et al. (2006) suggested that $V$. virens (Claviceps oryzae-sativae in his work) was an heterothallic fungus using a PCR-based assay. Here, we reexamined the $V$. virens mating type genes in single asexual-spore (chlamydospore) isolates and ascospores isolates collected from China and determined the mating type genotype using multiplex PCR. This multiplex PCR approach can be applied to investigate 
the distribution of mating types (Dyer et al., 2001). In addition, we analyzed the distribution of mating type genes in several isolates from the natural population.

\section{MATERIAL AND METHODS}

\section{Fungal isolates and culture conditions}

Isolates derived from conidia and ascospores used in this study are listed in Tables 1 and 2, respectively.

\section{Isolation from conidia}

These isolates were collected in southwestern and eastern China in 2011 and were obtained from naturally infected rice spikelets showing typical false smut symptoms. The yellowish rice kernels, which were covered with a mass of $V$. virens chlamydospores, were surface sterilized with $75 \%$ ethanol for 2 min and subsequently rinsed three times with sterile water. The treated specimens were resuspended into a chlamydospore suspension and diluted to $10^{3} \mathrm{ml}^{-1}$. An aliquot $(150 \mu \mathrm{l})$ of the spore suspension was poured onto potato dextrose agar (PDA) solid medium containing 100 $\mu \mathrm{g} / \mathrm{ml}$ chloramphenicol. The plate was incubated at $28^{\circ} \mathrm{C}$ in the dark. When visible colonies appeared, the colonies were transferred individually onto fresh PDA plates and incubated at $28^{\circ} \mathrm{C}$ in the dark. Each isolate was individually maintained at $4^{\circ} \mathrm{C}$ on a separate 9 -cm Petri dishes containing PDA solid medium.

\section{Isolation from ascospores}

Sclerotia were collected in the rice field and were buried in moist sterile sand at $25^{\circ} \mathrm{C}$ under light. The single ascospore was isolated as previously described (Singh \& Dubey, 1984). The isolates were maintained at $4^{\circ} \mathrm{C}$ as described above.

\section{DNA isolation and ITS-PCR}

Villosiclava virens mycelia were inoculated into 50 $\mathrm{ml}$ potato dextrose liquid and kept on an incubator-shaker at $150 \mathrm{rpm}$. The mycelia were harvested by filtration and ground to a powder in the presence of liquid nitrogen. DNA was isolated as reported by Murray and Thompson (1980), resuspended in deionized water, and stored at $-20^{\circ} \mathrm{C}$.

Specific internal transcribed spacer (ITS) primers were used to verify the identity of $V$. virens isolates. The polymerase chain reaction (PCR) mix $(50 \mu \mathrm{l})$ contained $2 \mathrm{U}$ polymerase (Takara), $5 \mu \mathrm{l}$ of $10 \times$ Taq buffer, 400 $\mathrm{mM}$ of dNTP's, $2 \mu \mathrm{mol}$ of DNA template and primers US1-5 and US3-3 (Table 3) (Zhou et al., 2003). PCR was performed using the following conditions: $96^{\circ} \mathrm{C}$ for 1 min, followed by 30 cycles of denaturing at $96^{\circ} \mathrm{C}$ for 20 $\mathrm{s}$, annealing at $58^{\circ} \mathrm{C}$ for $30 \mathrm{~s}$ and extension $72^{\circ} \mathrm{C}$ for 30 $\mathrm{s}$, followed by a final extension for $7 \mathrm{~min}$ at $72^{\circ} \mathrm{C}$. PCRamplified products were resolved by standard agarose gel electrophoresis and detected by Gelview (BioTeke) staining.

TABLE 1 - Isolates of conidia used in this study.

\begin{tabular}{|c|c|c|c|c|c|c|}
\hline Isolates & Locality & Longitude & Latitude & Strain number ${ }^{a}$ & MAT1-1-1 & $M A T 1-2-1$ \\
\hline Uvsf & Shifang & 104.16 & 31.19 & 8 & + & + \\
\hline Uvmy & Mianyang & 104.42 & 31.30 & 10 & + & + \\
\hline Uvdz & Dazhou & 107.29 & 31.14 & 6 & + & + \\
\hline Uvmz & mianzhu & 104.19 & 31.32 & 12 & + & + \\
\hline Uvnj & Neijiang & 105.02 & 29.36 & 9 & + & + \\
\hline Uvzg & Zigong & 104.46 & 29.23 & 7 & + & + \\
\hline Uvfa & Fuan & 119.39 & 27.06 & 6 & + & + \\
\hline Uvlz & Luzhou & 105.24 & 28.54 & 12 & + & + \\
\hline Uvsn & Shuining & 105.33 & 30.31 & 9 & + & + \\
\hline Uvkm & Kunming & 102.42 & 25.04 & 14 & + & + \\
\hline Uvcd & Chengdu & 104.04 & 30.40 & 26 & + & + \\
\hline Uvhf & Hefei & 117.17 & 31.52 & 12 & + & + \\
\hline Uvnc & Nanchong & 106.04 & 30.49 & 10 & + & + \\
\hline Uvfz & Fuzhou & 119.18 & 26.05 & 16 & + & + \\
\hline Uvya & Yaan & 102.59 & 29.59 & 10 & + & + \\
\hline Uvql & Qionglai & 103.34 & 30.26 & 7 & + & + \\
\hline Uvhz & Hangzhou & 120.10 & 30.16 & 10 & + & + \\
\hline Uvxc & Xichang & 102.16 & 27.54 & 14 & + & + \\
\hline Uvcz & Chongzhou & 103.40 & 30.39 & 8 & + & + \\
\hline NBRC31672 & Japan & & & 1 & + & + \\
\hline
\end{tabular}

${ }^{\mathrm{a} A}$ total of 206 isolates collected in 19 Chinese regions.

${ }^{+}$Detected. 
Mating type loci analysis indicates that Villosiclava virens, the casual agent of false...

TABLE 2 - Analysis of the mating type in single ascospores isolates.

\begin{tabular}{llccccc}
\hline \hline Isolates & Locality & Longitude & Latitude & Strain number $^{\text {a }}$ & MAT1-1-1 $^{\text {MAT1-2-1 }}$ \\
\hline Uvascd & Chengdu & 104.04 & 30.40 & 8 & + & + \\
Uvasq1 & Qionglai & 103.34 & 30.26 & 6 & + \\
Uvasya & Yaan & 102.59 & 29.59 & 5 & + & + \\
Uvnc & Nanchong & 106.04 & 30.49 & 7 & + & + \\
\hline
\end{tabular}

${ }^{\mathrm{a} A}$ total of 26 isolates.

${ }^{+}$Detected.

TABLE 3 - Primers used in this study.

\begin{tabular}{lll}
\hline \hline Genes & Primers & \multicolumn{1}{c}{ Sequences } \\
\hline \multirow{2}{*}{ ITS } & US1-5 & \\
& US3-3 & 5'-CCG GAG GAT ACA ACC AAA AAA ACT CT-3' \\
MAT1-1-1 & MAT1 F1 & 5'-GCT CCA AGT GCG AGG ATA ACT GAA T-3' \\
& MAT1 R1 & 5'-GAA ACT CYA ACT CAA ACR AAG TCG-3' \\
& MAT1 F2 & 5'-GKA AAC YTT GGC TAT CAR CGC CC-3' \\
& MAT1 R2 & 5'-GAA ACT CCA ACT CAA ACG AAG TCG-3' \\
& MAT2F1 & 5'-GTA AAC TTT GGC TAT CAA CGC CC-3' \\
& MAT2 R1 -1 & 5'-GGA GCR ACA TAA TAC CGT YAA AGA-3' \\
& MAT2F2 & 5'-GGR GTG TTT TWC TAA GAR GGC CT-3' \\
& MAT2 R2 & 5'-GGA GCG ACA TAA TAC CGT CAA AGA-3' \\
\hline
\end{tabular}

\section{PCR amplification of mating type genes and DNA sequencing}

The primers for the MAT1 genes were designed based on the high similarity to amino acid sequences of the alpha box and HMG box in Clavicipitaceae. We constructed two sets of primers (MAT1-F1/MAT1-R1, MAT2-F1/MAT2$\mathrm{R} 1$; Table 3) to amplify the relatively conserved MAT1-1 and MAT1-2 genes in $V$. virens.

PCR reactions were carried out in a $25 \mu \mathrm{l}$ volume containing $25 \mathrm{ng}$ DNA template, $20 \mathrm{mM}$ Tris- $\mathrm{HCl} \mathrm{pH}$ 8.4, $1.5 \mathrm{Mm} \mathrm{MgCl}_{2}, 200 \mathrm{mM}$ dNTP's, 25 pmol of each primer, and $1 \mathrm{U}$ Taq polymerase (Takara). Amplification conditions were $95^{\circ} \mathrm{C}$ for $1 \mathrm{~min}$, followed by 35 cycles of denaturing at $95^{\circ} \mathrm{C}$ for $30 \mathrm{~s}$, annealing at $56^{\circ} \mathrm{C}$ for 1 min and extension at $72^{\circ} \mathrm{C}$ for $40 \mathrm{~s}$, followed by a final extension for $7 \mathrm{~min}$ at $72^{\circ} \mathrm{C}$. The PCR amplicons were resolved, and their sizes were determined on a $1.2 \%$ agarose gel run in $0.5 \times$ TBE.

The amplicons of the MAT1-1 and MAT1-2 genes were excised from the gel and purified using a Gel Extraction kit (Axygen). The purified fragments were cloned into the pEASY-T1 vector (TransGene) according to the manufacturer's instructions. Sequences were obtained using Illumina GA technology, and analysis was carried out using the National Center for Biotechnology Information (NCBI) BLAST program.
Analysis of mating type gene distribution in natural
populations of Villosiclava virens in China

We designed two sets of specific primers (MAT1F2/MAT1-R2, MAT2-F2/MAT2-R2; Table 3) to amplify the $M A T$ genes in $V$. virens isolated from naturally infected rice spikelets showing typical false smut symptom by multiplex PCR. The PCR reaction mixture $(20 \mu \mathrm{l})$ contained $10 \times$ Taq buffer, $4 \mathrm{mM} \mathrm{MgCl}, 0.4 \mathrm{mM}$ each dNTP, $0.2 \mu \mathrm{M}$ of each of the four primers and $1 \mathrm{U}$ of Taq DNA polymerase (Takara). PCR products were amplified according to the following conditions: initial denaturation at $95^{\circ} \mathrm{C}$ for $1 \mathrm{~min}$, follow by 40 cycles of denaturing at $95^{\circ} \mathrm{C}$ for $30 \mathrm{~s}$, annealing at $56^{\circ} \mathrm{C}$ for $40 \mathrm{~s}$ and extension at $72^{\circ} \mathrm{C}$ for $40 \mathrm{~s}$, and a final elongation step for $7 \mathrm{~min}$ at $72^{\circ} \mathrm{C}$.

\section{RESULTS}

\section{Isolation and characterization of Villosiclava virens}

Chlamydospores of $V$. virens germinated easily on PDA medium. Colonies appeared as white dots at 5 days after inoculation. As the fungus grew, the colony gradually resembled white bread (Figure 1). A single colony of $V$. virens was transferred and maintained in a fresh culture. In this study, we obtained 206 conidia isolates from southwestern and eastern China (Table 1) and 26 ascospore isolates (Table 2). 
The identity of the pathogen was further verified by ITS-PCR. The specific primers of $V$. virens amplified a 380bp product (Figure 2) from all the isolates specific to the false smut pathogen.

\section{Identification of MAT1-1 and MAT1-2}

After DNA extraction from asexual single spore isolates, their mating type genes were identified by PCR amplification. The results showed that $V$. virens possesses two types of mating type loci, MAT1-1-1 and MAT1-2-1. The genomic sequences of the MAT1 genes have been deposited in GenBank (accession numbers KC920891 and KC920892). In the MAT1-2-1 gene sequences,

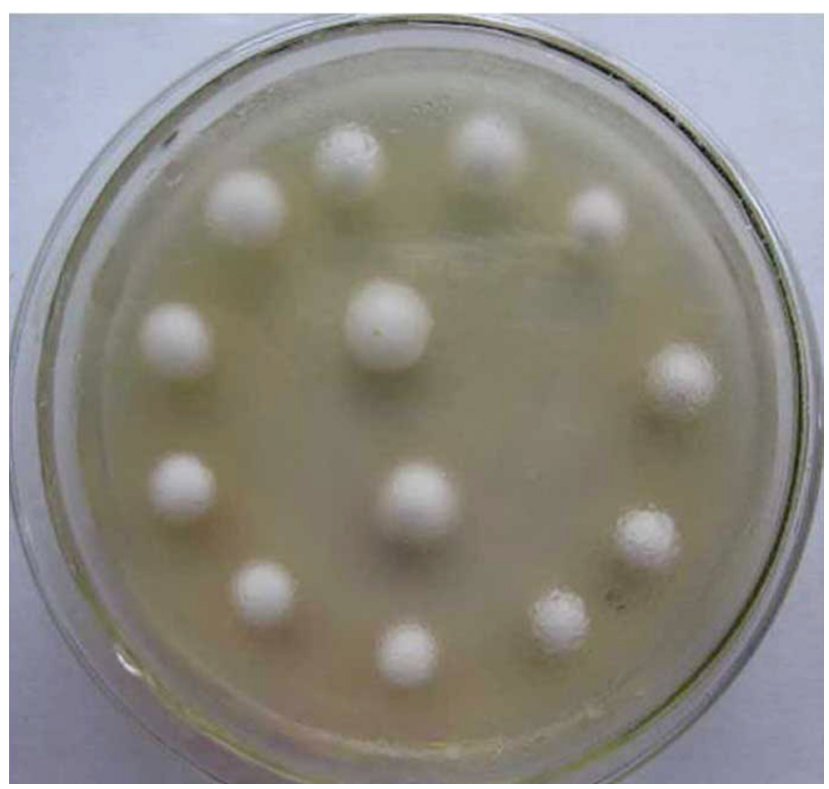

FIGURE 1 - Colony morphology of asexual spores (chlamydospores) germination (5 days). comparison of KC920892 with AB124632 (which was already deposited in GenBank) indicated 89\% identity. The length of the mating type genes MAT1-1-1 and MAT1-2-1 were $256 \mathrm{bp}$ and $222 \mathrm{bp}$, respectively (Figure $3)$.

\section{Mating type gene distribution in natural populations}

The presence and distribution of mating type genes collected from natural populations of the fungus were estimated using a multiplex PCR method. As shown in Table $1, V$. virens isolated from each local population contained both MAT1-1 and MAT1-2 genes.

\section{V. virens resulting from selfing}

To confirm our hypothesis that $V$. virens is derived from selfing and that it is a homothallic fungus, we performed multiplex PCR using two sets specific primers (MAT1-F2/MAT1-R2 and MAT2-F2/MAT2-R2) to screen mating type genes in ascospore isolates. The results showed that the ascospore isolates exhibited both MAT1-1-1 and MAT1-2-1 genes (Figure 4). These results suggested that $V$. virens is self-fertile and does not need the participation of a partner.

\section{DISCUSSION}

In this study, the ITS from all isolates tested, including the reference strain for $V$. virens, showed 99.9 to $100 \%$ sequence similarity, confirming that these isolates are genetically closely-related.

Fungal mating type genes play an important role in regulating sexuality, virulence and survival. Sun et al. (2013) have reported that the genetic diversity of $U$. virens was high in some areas of China. In this study, we used asexual spores to amplify the mating type genes of $V$. virens and found that a single asexual spore isolate carries both MAT1-1-1 and MAT1-2-1 genes. This

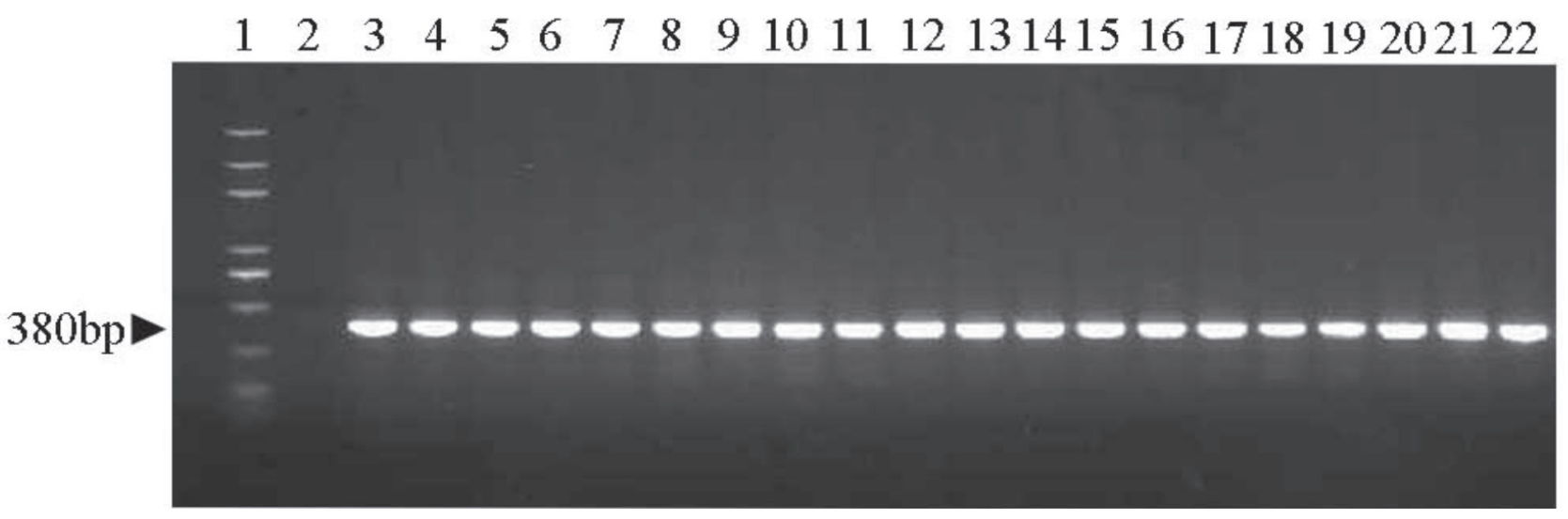

FIGURE 2 - Gelview-stained agarose gel showing representative results of PCR amplification of the ITS regions of $V$. virens isolates. Lane 1, DNA marker (Trans2K, TransGen); lane 2, negative control; lane 3, positive control; lanes 4-22, isolates Uvsf2, Uvmy5, Uvdz1, Uvmz10, Uvnj9, Uvzg7, Uvfa1, Uvlz9, Uvsn1, Uvkm1, Uvcd1, Uvhf10, Uvnc1, Uvfz12, Uvya10, Uvq16, Uvhz9, Uvxc12, Uvcz8. 

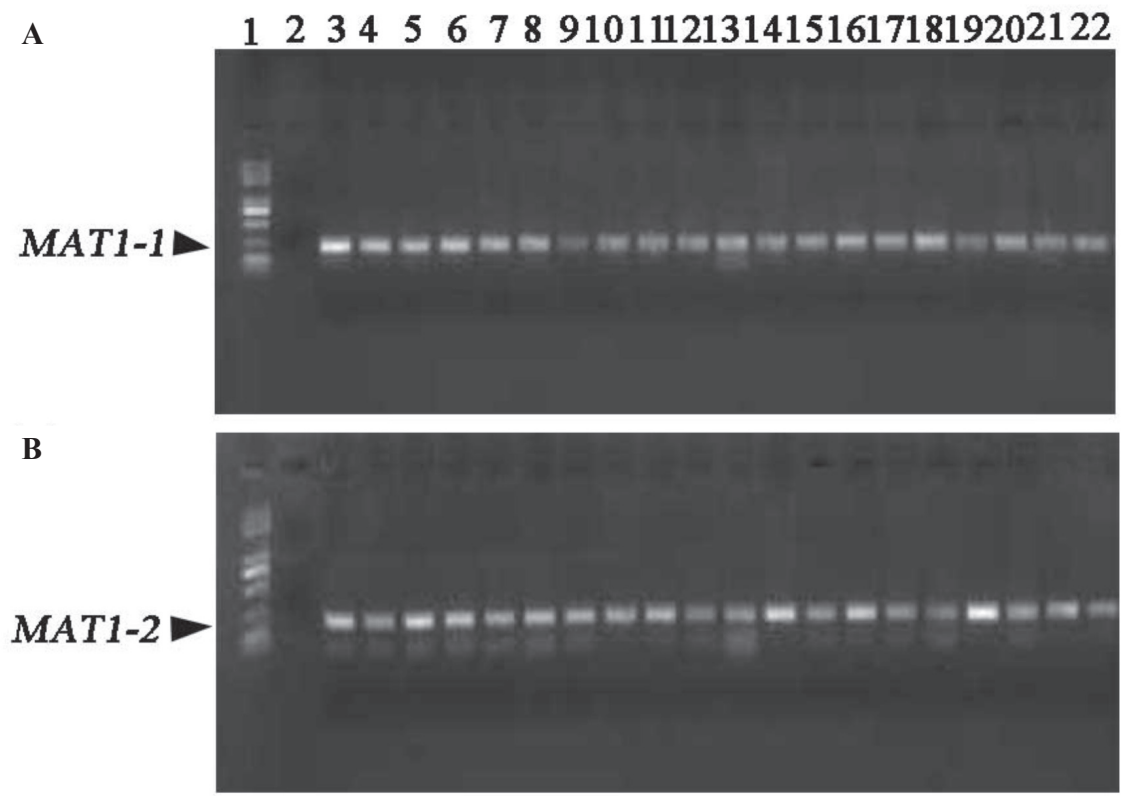

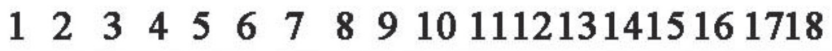

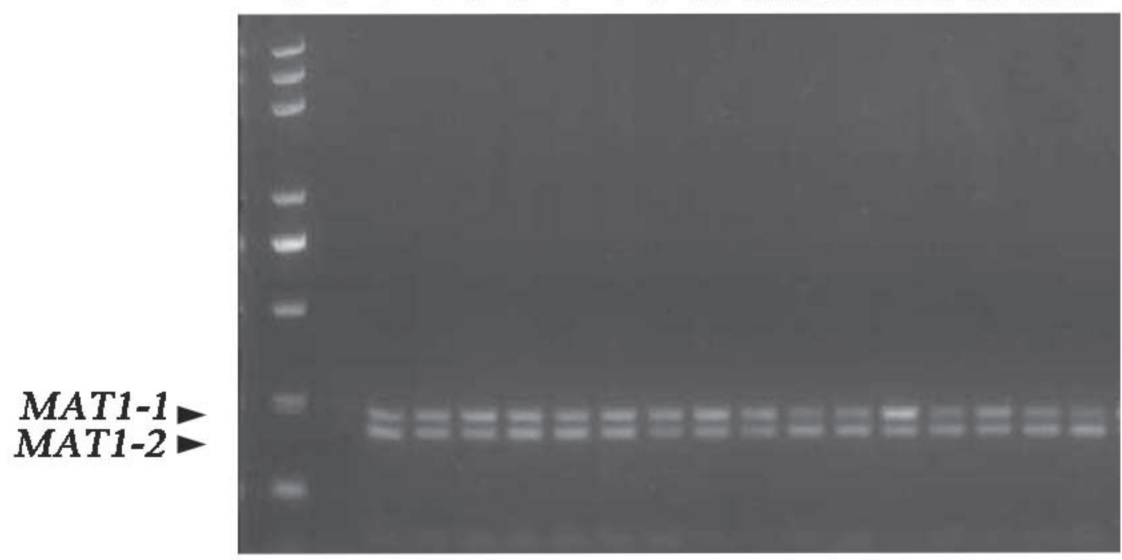

FIGURE 3 - Goldview-stained agarose gel showing representative results of PCR amplification of mating-type gene fragments in $V$. virens isolates. A. Fragment of MAT11-1 gene (256 bp) (accession number KC920891); B. Fragment of MAT12-1 (222 bp) (accession number KC920892). Lane 1, DNA marker (Trans2K, TransGen); lane 2, negative control; lane 3 positive control; lanes 4-22, isolates Uvsf2, Uvmy5, Uvdz1, Uvmz10, Uvnj9, Uvzg7, Uvfa1, Uvlz9, Uvsn1, Uvkm1, Uvcd1, Uvhf10, Uvnc1, Uvfz12, Uvya10, Uvq16, Uvhz9, Uvxc12, Uvcz8.

\begin{abstract}
FIGURE 4 - Multiplex PCR amplification of mating-type genes from representative ascospore isolates. Lane 1, DNA marker (Trans2K, TransGen); lane 2, negative control; lanes 3-18, isolates Uvascd1, Uvascd2, Uvascd6, Uvascd8, Uvasq12, Uvasq13, Uvasq15, Uvasq16, Uvasya1, Uvasya2, Uvasya3, Uvasya5, Uvasnc2, Uvasnc3, Uvasnc5, Uvasnc6.
\end{abstract}

result differs from those reported by Yokoyama et al. (2006), who found only MAT1-2 gene in U. virens. This difference may be due to primer design and PCR conditions. Mating type genes have previously been described in several heterothallic and homothallic filamentous fungi as master regulators of sexual compatibility and sexual reproduction (Casselton, 2002; Kronstad 2007; Paoletti et al., 2007). These genes in homothallic fungi are usually linked. An exception is self-compatible Neurospora africana L.H. Huang \& Backus, which contains only MAT-A-1 present in the genome (Glass \& Smith, 1994). Homothallic fungi such as $A$. nidulans are also cross-fertile (Pontecorvo et al., 1953). Pontecorvo et al. (1953) propose the term "relative heterothallism" to explain the ability of a homothallic species to cross-fertilize. Several studies suggest that sexual identity in homothallic systems might be regulated by differential expression of mating type genes or selective epigenetic silencing one of two MAT genes (Raju \& Perkins, 2000; Pöggeler, 2002; Scazzocchio, 2006). Further research is necessary to determine whether or not the MAT genes in the genome of $V$. virens are linked.

In this study, we developed a simple and reliable multiplex PCR-based marker for determining the distribution of mating type genes in $V$. virens, and our results showed that all isolates displays both $M A T$ genes. Furthermore, the multiplex PCR codominant marker was used to screen mating type genes in ascospore isolates, and the results showed that the ascospore isolates exhibited both MAT1-1-1 and MAT1-2-1 genes. The results provide further evidence that $V$. virens is a homothallic fungus (Yun et al., 2000; Debuchy \& Turgeon, 2006). The 
multiplex PCR was also used to ascertain the heterothallism in the ascomycete Tuber melanosporum (Rubini et al., 2011). Our studies suggest a novel reproductive mechanism of $V$. virens. Determination of the mating type of field isolates may provide important insights into the genetic basis and molecular mechanism of reproduction in $V$. virens.

\section{ACKNOWLEDGEMENTS}

This work was financially supported by the Ministry of Agriculture of China (No. 2008ZX08009003).

\section{REFERENCES}

Bulter G (2010) Fungal sex and pathogenesis. Clinical Microbiology 23:140-159.

Bischoff JF, Sullivan RF, Kjer KM, White JF Jr (2004) Phylogenetic placement of the anamorphic tribe Ustilaginoideae (Hypocreales, Ascomycota). Mycologia 96:1088-1094.

Casselton LA (2002) Mate recognition in fungi. Heredity 88:142-147.

Dyer PS, Furneau X, Douhan G, Murray D (2001) A multiplex PCR test for determination of mating type applied to the plant pathogens Tapesia yallundae and Tapesia acuformis. Fungal Genetics and Biology 33:173-180.

Debuchy R, Turgeon BG(2006) Mating-type structure, evolution and function in Euascomycetes. In: Kües U, Fischer R (Eds.) The Mycota Vol. I. Growth, Differentiation and Sexuality. Amsterdam, The Netherlands. Springer. pp. 293-323.

Fraser JA, Heitman J (2005) Chromosomal sex-determining regions in animals, plants and fungi. Current Opinion in Genetics and Development 15:645-651.

Fu RT, Ding L, Zhu J, Li P, Zheng AP (2012) Morphological structure of propagules and electrophoretic karyotype analysis of false smut Villosiclava virens in rice. Journal of Microbiology 50:263-269.

Glass NL, Smith ML (1994) Structure and function of a matingtype gene from the homothallic species Neurospora africana. Molecular and General Genetics 244:401-409.

Hayden HL, Carlier J, Aitken EAB (2003) Genetic structure of Mycosphaerella fijiensis populations from Australia, Papua New Guinea and the Pacific Islands. Plant Pathology 52:703712 .

Kronstad JW (2007) Self-fertility: The genetics of sex in lonely fungi. Current Biology 17:R843-R845.

Koiso HC, Li Y, Iwasaki S, Hanaoka K, Kobayashi T, Sonoda R, Fujita Y, Yaegashi H, Sato Y (1994) Ustiloxin, antimitotic cyclic peptides from false smut balls on rice panicles caused by Ustilaginoidea virens. Journal of Antibiotics 47:765-773.

Murray MG, Thompson WF (1980) Rapid isolation of high molecular weight plant DNA. Nucleic Acids Research 8:43214326.

Metin B, Findley K, Heitman J (2010) The mating type locus (MAT) and sexual reproduction of Cryptococcus heveanensis: Insights into the evolution of sex and sex-determining chromosomal regions in fungi. PLoS Genetics 6:1-19.

Marais G, Galtier N (2003) Sex chromosomes: How XY recombination stops. Current Biology 13:R641-R643.

Pöggeler S (2002) Genomic evidence for mating abilities in the asexual pathogen Aspergillus fumigates. Current Genetics 42:153-160.

Paoletti M, Seymour FA, Alcocer MJC, Kaur N, Calvo AM, Archer DB, Dyer PS (2007) Mating type and the genetic basis of self-fertility in the model fungus Aspergillus nidulans. Current Biology 17:1384-1389.

Pontecorvo G, Roper JA, Hemmons LM, MacDonald KD, Bufton AW (1953) The genetics of Aspergillus nidulans. Advances in Genetics 5:141-238.

Rubini A, Belfiori B, Riccioni C, Tisserant E, Arcioni S, Martin F, Paolocci F (2011) Isolation and characterization of MAT genes in the symbiotic ascomycete Tuber melanosporum. New Phytologist 189:710-722.

Raju NB, Perkins DD (2000) Programmed ascospore death in the homothallic ascomycete Coniochaeta tetraspora. Fungal Genetics and Biology 30:213-221.

Sakurai M (1934) On the causal fungus of rice false smut. Annals of the Phytopathological Society of Japan 3:70-71.

Scazzocchio C (2006) Aspergillus genomes: Secret sex and the secrets of sex. Trends in Genetics 22:521-525.

Singh RA, Dubey KS (1984) Sclerotial germination and ascospores formation of claviceps oryzae- sativae in India. Indian Phytopathology 37:168-170.

Sun XY, Kang S, Zhang YJ, Tan XQ, Yu YF, He HY, Zhang YF, Wang S, Sun WX, Cai L, Li SJ (2013) Genetic diversity and population structure of rice pathogen Ustilaginoidea virens in china. PLoS One 8:1-11.

Takahashi Y (1896) On Ustilago virens Cooke and a new species of Tilletia parasitica on rice plant. Botanical Magazine Tokyo 10:16-20.

Tanaka T, Ashizawa T, Sonoda R, Tanaka C (2008) Villosiclava virens gen. nov., com. nov., teleomorph of Ustilaginoidea virens, the causal agent of rice false smut. Mycotaxon 106:491501.

Tang YX, Jin J, Hu DW, Yong LM, Xu Y, He LP (2013) Elucidation of the infection process of Ustilaginoidea virens (teleomorph: Villosiclava virens) in rice spikelets. Plant Pathology 62:1-8.

Turgeon BG, Yoder OC (2000) Proposed nomenclature for mating type genes of filamentous ascomycetes. Fungal Genetics and Biology 31:1-5.

White JF Jr, Sullivan R, Moy M, Patel R, Duncan R (2000) An overview of problems in the classification of plant-parasitic Clavicipitaceae. Studies in Mycology 45:95-105.

Yun SH, Arie T, Kaneko I, Yoder OC, Turgeon BG (2000) Molecular organization of mating type loci in heterothallic, homothallic, and asexual Gibberella/Fusarium species. Fungal Genetics and Biology 31:7-20.

Yokoyama E, Arakawa M, Yamagish K, Hara A (2006) Phylogenetic and structural analyses of the mating-type loci in Clavicipitaceae. FEMS Microbiology Letters 264:182-191. 
Mating type loci analysis indicates that Villosiclava virens, the casual agent of false...

Zhou YL, Izumitsu K, Sonoda R, Nakazaki T, Tanaka T, Tsuda M, Tanaka C (2003) PCR-based detection of Ustilaginoidea virens and Ephelis japonica. Journal of Phytopathology 151:513-518.

TPP-2013-0180

Submitted: 26 October 2013

Revisions requested: 26 November 2013

Accepted: 30 December 2013

Section Editor: Meike Piepenbring 